Article

\title{
The Riding Trail as Geotourism Attraction: Evidence from Iceland
}

\author{
Guðrún Helgadóttir ${ }^{1,2, *}$ and Ingibjörg Sigurðardóttir ${ }^{2}$ \\ 1 Department of Business and IT, University of South-Eastern Norway, Gullbringvegen 36, \\ 3800 Bø i Telemark, Norway \\ 2 Rural Tourism Department, Hólar University College, Háskólinn á Hólum, Hólar í Hjaltadal, \\ 551 Sauðárkrókur, Iceland; inga@holar.is \\ * Correspondence: gudrun.helgadottir@usn.no
}

Received: 20 August 2018; Accepted: 9 October 2018; Published: 12 October 2018

check for updates

\begin{abstract}
The geological aspects of tourism are much more extensive than just places to be viewed and/or experienced. The terrain traveled is also a geological phenomenon and an attraction in itself. For a hiker or a rider the type of trail is important. Features of the trail such as the gradient, altitude, the soil qualities, the length and the vistas it affords are important geological considerations. The trail as an experienced geological attraction, or should we say, the foundation for horse based tourism, particularly long rides, is the topic of this paper. The research is based on different sources. Existing data from earlier research on the Icelandic horse industry and equestrian tourism are used, as well as eight interviews conducted for this study. Further, the authors use their personal experiences as riders and horse tourists to reflect on the topic. Findings indicate that the riding trail and its surroundings can be defined as geosites and equestrian tourists as casual geotourists. The trails as geosites have different values for its stakeholders. The trails seem to have values such as scientific/educational, cultural/heritage, scenic and touristic values, just as other geosites. Furthermore, we argue that riding trails do have an economic value, as well as an emotional/romantic value.
\end{abstract}

Keywords: geotourism; riding trails; horseback riding; heritage; experience value

\section{Introduction}

Riding, as other modes of traveling, has impacts that various stakeholders interpret differently. To a rider, the existence and condition of the trail signals whether the terrain is passable, it suggests the speed and gait that the horse can maintain, the distance that can be traveled without rest and the need for shoeing the horses. It is therefore an important issue in horse tourism, to know what kind of trails riders prefer and to have access to trails that are both desirable for horses and people, as well as being sustainable from a conservation point of view. For experienced riders the trail itself, the terrain for riding is an attraction in its own right. Thus, we argue that the trail is a geotouristic phenomenon as riders choose trails depending their geological qualities such as soil and landforms. Furthermore, we argue that in horse tourism attention must be paid to geosite conservation and attraction.

Despite the above discussed importance of riding trails as geotouristic phenomenon and as a part of the experience of tourists traveling by horses, research on riding trails and different aspects related to riding trails around the world is scarce. Trails have been defined as an important part of the infrastructure for development of equestrian tourism and the horse industry in general [1]. The importance of riding trails as a part of tourist's experience when traveling with horses has been briefly addressed in earlier research [2,3]. It should be noted that here we are discussing trails both constructed by humans and trails formed by the hooves of animals without riders. 
This research owes much to research on hiking trails. Annette Bischoff [4] for example, asked participants in her study to define the phenomenon "trail" or sti, in Norwegian. She concluded that a trail is narrow, runs through vegetation and can have roots and rocks in the surface; it is not for vehicle traffic; it inspires confidence/safety and a feeling of community; it is an opportunity for and access to experiences and places; it connects past and present and places people in holistic context; and that through our lives we carry within us trails that are either concretely paths to places we like or a particular type of trail that we seek out wherever we go. Furthermore, that the materiality of the trail is created in a nature-culture dynamic; that the trail and its materiality is formed by embodied and social practice; experiences are embodied in the interplay of senses in meeting the materiality and that the trail and its environment is in constant change under the volatile elements [4]. The point made here about the materiality of trails leads us to consider the 'geo' as in geotourism.

\subsection{Geotourism}

The concept of a geosite is young and has been developing in recent decades towards a wider approach than before, including tourism. The concept has been discussed and defined by a number of academics including Ólafsdóttir and Dowling [5] who see geosites as tools for geoconservation and rural development in vulnerable arctic environment as in Iceland. They further emphasize that geotourism can have a role "to minimize the negative impacts of mass tourism in geologically and geographically situated tourist environments" [5].

Geotourism has been defined as a sub-sector of nature tourism with its own issues, management and impacts [6]. The geotourism concept was first introduced in early 1990s. First definitions focused on the geosites, the landforms and the geological formations as the attraction, as well as its geotourists and geoeducational potential [7]. More holistic approaches were developed later. Even in the early definitions, some attention was paid to the presence of humans and the nature-culture connection rather than divide-albeit as almost an afterthought: "Furthermore, landscapes and some geosites provide for aesthetic values and cultural, historical and adventure tourism" [8]. The focus was on the human as tourist in the geotourism equation, particularly the nature and adventure tourist as geotourist.

As Ólafsdóttir and Tverijonaite [9] show in their review of geotourism literature the definitions of geotourism have broadened to include the bios in the geo and to focus on the cultural heritage of landscape. That is the focus is no longer only on geoforms as geological heritage. The landscape, which is a cultural phenomenon, a heritage created by humans and animals for sustainable living in the land. Trails are an example of such heritage landscape phenomena.

Despite the fact that geotourism is reputed to have a number of essential characteristics it is also related to other forms of tourism as adventure tourism, ecotourism and cultural tourism [6]. Geosites can be attractions both for passive recreation, as well as more active engagement [10] such as hiking and riding. We have argued elsewhere that horse based tourism is simultaneously a form of nature tourism [11], event tourism [12], adventure tourism [3,13], farm tourism [14], wellness tourism [13] and cultural tourism [15].

Here, we do not extend the definition of horse tourism to geotourism as a special attraction, but articulate that riders are casual geotourists and important stakeholders in the conservation and use of geosites. The focus on stakeholders, such as the users of riding trails and the communities of riders, horse farmers and the non-human actors in this case horses, answers to one of the main research gaps identified [9].

\subsection{Geosites and Their Values}

Research on riding trails as a geotouristic phenomenon or a part of a geosite is limited as well as on the value of geosites [16]. This research addresses the value of trails and its surroundings as geosites.

"Geosites [ ... ] are the key localities for Earth sciences" and have been defined in different ways [16]. Up to 21 types of geosites have been distinguished based on the subject matter [16]. 
Thus, some geosites may essentially be points (e.g., small natural rock outcrop amidst otherwise vegetated terrain), others can be linear (e.g., sections of river channels), and yet others may encompass fairly large areas of natural features (e.g., fields of collapsed pingos or roche moutonnées) or anthropogenic objects (e.g., large quarries) [16].

Further work on classification and definition of geosites rests on analyses of their interpretive score and heritage value, that is, how well the sites afford visitors an understanding of geological processes and what their potential is for visitation and conservation [17,18]. Another way to look at this is to identify which value can be added and use for society, distinguishing between scientific value and cultural values, such as aesthetic and/or socioeconomic [19].

Several kinds of geosite values have been identified in recent studies. Brilha [17] and Erikstad, Nakrem and Markussen [20] are among the ones who have analyzed the scientific value of geosites. Touristic, educational and cultural values are also mentioned [17] as well as geological and geoheritage values [20] and scenic values [16]. The relations of those values are pointed out, particularly regarding scientific and educational values on one hand and cultural and heritage values on the other hand [20]. The issue of visitor safety is addressed in a study on viewpoint geosites [16]. Despite the risk of traveling by horses, the importance of the safety of riding trails for tourists in equestrian tourism in Iceland has shown to be less than the importance of the trails being interesting, varied and suitably long [3].

\subsection{Natural and Cultural Heritage}

Sustainable geotourism as other human activities cannot be conceptualized without reference to the notion of heritage as that which present generations value from the past and wish to conserve for the future [21]. The term heritage is perhaps more often associated with culture, and heritage tourism research and development focuses on this. Yet there is a growing interest in natural heritage tourism as part of nature-based tourism [21]. Nature phenomena are also subject to the discovery and invention as heritage, even labelled as heritagization, which is not altogether uncontested as it may result in the suppression of human activity and thereby harm local people [22,23]. Nature conservation areas, national parks and protected sites are an important tool in the process of recognizing and meeting diverse stakeholder needs and creating experiential and emotional value through heritage designation. Geodiversity, as biodiversity, is subject to conservation efforts, necessitating classification and deep understanding of geodiversity as an important factor in areal planning, land use and conservation policies as well as principles for tourists and tourism operators [24,25].

This builds up to a more nuanced understanding of geoheritage, with the rising emphasis on ecosystem services and cultural ecosystem services rooted in the biocentric understanding of humans as part of nature, rather than outside agents impacting nature [26,27]. The European Landscape Convention is an example of the conservation and resource management policies that take this as their point of departure in defining landscape as "an area, as perceived by people, whose character is the result of the action and interaction of natural and/or human factors" [28].

This ideology widens the concept of geoheritage considerably to include the built environment, or anthropogenic objects, which partly at least, are made of local geological materials $[17,26,28]$. While the reader may first think of buildings as built environment, there are extensive infrastructures such as the transportation network that make up much of the built environment. Roads, bridges, airfields, harbors, and last but not least, trails made by humans and their domesticated animals, that are part of geoheritage and vital infrastructure for tourism.

\subsection{The Importance of and Issues around Riding Trails}

Trails are of importance for different kinds of recreational activities and defined as important infrastructure for activities such as hiking and riding. Considerable research on different critical factors regarding hiking trails exists, as e.g., on trampling, disturbance, trail widening and deepening and conflicts between different groups of trail users. Despite the rising number of horses in Iceland 
(about 70,000 in 2014 compared to about 30,000 in 1965) [29] and the prevalence of riding tourism [30], research on riding trails and aspects related to them in Iceland is scarce. Equestrian tourism is one of the most popular activities undertaken by about $15 \%$ of international tourists in Iceland with a high record of visitor satisfaction [31].

The riding trail can be an anthropogenic object or it can be formed by animals without direct human input. No matter how the trail has been formed, it is always a part of the landscape. Impacts of recreational activities as hiking, mountain biking and horse riding on land can differ and depend highly on soil and weather conditions. "Impacts include damage to existing trails, soil erosion, compaction and nitrification, creation of informal trails and the spread of weeds and plant pathogens" [32]. The impacts of horse riding are mostly comparable with the impacts of hiking. Horses are however heavier than humans are, and consequently, riding has greater impacts on trails as well as causing stakeholder conflict with other users by their presence and their droppings [33]. Specifically, the problems with droppings and trampling are defined as "nitrification of soil and waterways from horse manure and the spread of weeds" [32]. Guidelines for minimizing negative effects of horse riding in peri-urban nature reserve have been made in Australia [34] and management strategies for horse riding in protected areas has also been created in Australia [35].

The importance of riding trails and other related infrastructure for travelers' experience and willingness to visit tourism destinations is recognised. Blackwell, Pagoulatos, Hu and Auchter [36] estimated the value of multi-use trails by analyzing "individuals' visitation behavior consistent with a travel cost model" (p. 229) through a survey of 188 trail riders, that people bring their own horses to a destination for riding. They found that improvement of trails and facilities for riders and horses was likely to increase the number of revisits and length of stay of those visitors [36].

Lack of riding trails and/or accessibility to trails and lack of available information on trails is among the factors affecting development of equestrian tourism and the experience of local residents and visitors traveling by horse $[1,37]$. The importance of developing riding trails away from the vehicle traffic has been pointed out. On one hand to increase the safety of riders (and drivers) as an increasing number of drivers has limited knowledge about how to approach horses $[1,3]$ and on the other hand, to improve and enrich the experience of riders, including getting closer to nature and experiencing the natural surroundings and landscape $[15,37]$.

The importance of accessible riding trails has been emphasized in Iceland. To sustain old traditional riding trails which have been formed in the landscape and used for centuries by generations living in the rough and roadless Iceland, is seen as a part of cultural heritage and important for the experience of domestic and international riders [38]. In Iceland "there are few environmental impacts through equestrian tourism in national parks and protected areas" [39]. The main impacts noted in a study on this issue in Iceland were that trails did become deeper and sometimes multiple parallel trails were forming and that hay brought into the areas to feed horses did transfer seeds to areas devoid of grass. The extent of the impacts varied between different protected areas [39]. It has been pointed out that in a destination such as Iceland, where nature based tourism takes place in "very fragile environments, good monitoring techniques becomes even more important" for managing infrastructure as hiking trails [40].

In a strategy for tourism in Iceland in 1996, the importance of ensuring that riding trails were developed with reference to environmental issues and in collaboration with governments and local authorities, was defined as an important premise for sustainable development of equestrian tourism [41].

The northwest part of Iceland, including Skagafjordur region, has a long history of equestrianism. In the tourism strategy for Skagafjörður 2006-2010 the importance of historic riding trails is highly emphasized as an opportunity for product development in tourism to enrich visitors' experience [42]. The region has the highest ratio of horses per person in Iceland; 2.6 horses per person [30] and an active horse industry at all levels of the value chain, including equestrian tourism $[43,44]$. 


\subsection{Experiencing the Trail}

Research on trails has, to a great extent, focused on the impacts, in the tradition of placing humans outside nature. Less has been done to research the experiences of trail users. Research on the experiential value of trails for tourists is of importance here. While little is known about the experience value riders have, the experience of hikers may offer some clues.

Nordbø and Prebensen [45] found that the three most important experience attributes identified by hikers were physical and mental benefits and the physical attributes and facilitation of the trail. That is the trail itself; finding it, keeping it and enjoying it are crucial factors in the experience of hikers. Bischoff [4] calls the experience attributes types of access to nature and environment that is through knowledge and understanding; a physical, embodied access; an aesthetic and an affective and spiritual access (220). Nordbø and Prebensen [45] do not elaborate the facilitation and physical attributes of trails in depth in their study, as their focus is more on the mental and physical benefits of hiking.

Bischoff [4] concludes that the experience that hikers have of nature through trails is emotional, spiritual and mental, even transcendental. Furthermore, that it can be mundane and extraordinary and that there is an absence of built elements in the environment. Feelings of freedom, balance and flow, of relating and/or belonging in nature; of experiencing oneself, are the topics identified in her study.

A survey among Icelandic customers of horse tourism businesses showed correspondence between overall visitor satisfaction and the quality of the riding trails where three criteria were most important: Enjoyable, of suitable length, and variety [2]. It was surprising that safety of the trail did not rank higher. The criteria are further elaborated in Sigurðardóttir and Helgadóttir [3]:

"Functionally, a trail must be passable and safe, the terrain firm and the path clear of danger from other types of traffic. Aesthetically, it should be offering nice views, free from disturbing noises, odours and with minimal discomfort for horses and people".

Bischoff [4] found that different types of trails lead to different types of engagement; broad and straight trails increase the speed of travel and shift the focus from the path taken while narrow, winding trails make the traveler focus inward and downward to the path and its immediate environment, thereby making for more of a nature experience.

Further research using qualitative methods sheds light on the meanings that riders attach to those criteria.

\subsection{The Terrain}

Iceland is a volcanic island located in the Mid-Atlantic Ridge. It is $103,000 \mathrm{~km}^{2}$ in size. It has been defined as the youngest country in Europe with " 22 active volcanoes, 250 geothermal areas, 780 hot springs, and the world's third largest ice-cap. It is one of the world's most active hot-spots with one-third of all the lava to surface on Earth in the last 1000 years being of Icelandic origin" [46]. Although volcano tourism is not particularly a subject of this paper it is worth noticing that "volcano tourism is an important sector of geotourism, which includes the geodiversity and the geological heritage of unique landscape features [10]. Volcanic landscapes are sites for geotourism, adventure tourism, health/wellness tourism and ecotourism [10].

Bischoff [4] also found that the soil on the trail is an important attribute; soil types make different noises, have different scents and feel different underfoot, while light and shadow, wind and temperature affect the soil and the hiker. As the focus here is on the soil, as an aspect of trails, it needs to be emphasized that volcanic ash and lava are, of course, prevalent in parts of the network of traditional horse trails in Iceland.

\subsection{Riding and the Native Horse as a Heritage}

Native horse breeds exist worldwide. Horsemanship and equestrian tourism based on native breeds has been described in Europe [47,48] and other parts of the world, such as in Nepal [49], Mongolia [50] and Kyrgyztan [51,52]. But what is a "native breed"? "Their association with their 
homelands and native landscapes mark them as special, and the term "native breed" suggests a naturalness removed from the conscious, "civilized", aristocratic breeding programmes of the 18th and 19th centuries in Europe" [41]. Tourism where native horse breeds are used has gained increased attention in recent years. Not least as it builds on the traditional use of the horse and of riding trails, which relate to the local landforms and the history of communities and nations.

The Icelandic horse is a native breed in Iceland and the only horse breed in the country. It was brought to Iceland during settlement and there has been no outcross with other horse breeds for centuries. The horse is a purebred, gaited, and rather small riding horse [53]. Evans [48] sees native breed tourism as part of cultural heritage tourism and a part of cultural landscapes. This is in line with earlier findings of Helgadóttir [14] on the culture of traveling with horses in Iceland, suggesting that in the culture of horsemanship there is a notion of breeding and training traditions for the Icelandic horse as heritage that should be preserved, and this notion is also used in marketing horse-based tourism in Iceland. The traditions of traveling with horses are an important part of this heritage as it is a very popular aspect of horsemanship in Iceland [15].

It is worth noting that this emphasis on the native breed in the landscape of origin coincides with the rising interest in local produce, slow living and slow travel concepts that call for experiential authenticity in tourism landscapes. The arts more so than the sciences increase our understanding of this.

Icelandic literature, particularly poetry and rhymes, the relation of rider, horse and landscape is one of the topics often examined [15]. Hafstein [54] expresses feeling as if the mountains fly towards him and the wind kisses his cheek as the horse gallops. Another romantic poet and a renowned equestrian often used the image of the horse writing on the ground or on ice, with its gait [55].

In a historical poem about a flight, the horse is thanked for the escape through its ability to ride a rough terrain —on good trails the game was even, but as they rode into the mountains, the heroic horse takes the lead. It gallops without regard for crevasses, rifts, rocks and charges on in a thick cloud of earth, lava and black sand [56]. The horse as a hero or a partner to a heroic deed by a human is a phenomenon in horse cultures worldwide [11,57].

\section{Methodology}

One of the quality aspects we have investigated in horse tourism is what attributes of trails the horse tourist in Iceland prefers. The questionnaire used in our earlier visitor surveys does not lend itself to probing deeper meanings that respondents attach to the items, so that it is not quite clear what is, for instance, meant by a trail being interesting [3]. Diversity and length are somewhat easier to assess. The interviews with riders and horse entrepreneurs shed further light on the topic of experiencing the trail and landscapes.

The research for this paper is longitudinal and based upon on interviews with domestic horse tourists and horse tourism entrepreneurs. Here we summarize results on the topic of trail experience from semi structured interviews with equestrian tourism entrepreneurs and horse farmers from previous studies and add new interview material from domestic horse tourists, gathered for this article. Further, the authors use their personal experiences as riders and horse tourists to reflect on the topic.

The interviews were semi-structured and analyzed by identifying themes, categories and relevant items of information which are reflected in the headings of the findings. The sampling of this research can be described as non-probability purposive sampling as the interviewees conform to the criterion of being particularly knowledgeable about the issues under investigation [58]. The interviewees were asked to describe their experience of riding different kinds of trails in variable landscape. They were further asked to describe what kinds of trails they preferred when riding on one hand with tourists and on the other hand by themselves.

As described earlier, data was gathered in three levels:

A. At the first level, the main focus of the interviews was on horse tourism business entrepreneurship, the people interviewed (horse breeders and horse tourism entrepreneurs) 
often discussed the trails and terrain for riding. The interviews took place at the respondents residence or place of business and were audio recorded and later transcribed. Respondents were anonymized with fictional names. A total of 21 interviews were conducted at this level. In this paper we have replaced the fictional names with a letter and number (e.g., A-1). Demographics of the responding entrepreneurs can be seen in Table 1.

Table 1. Demographics of responding horse entrepreneurs (A).

\begin{tabular}{ccccc}
\hline No & Gender & Nickname & Age & Professions in the Horse Field \\
\hline A-1 & female & Margret & $50-59$ & Breeding, horse shows for tourists \\
A-2 & female & Erla & $60-69$ & Breeding \\
A-3 & male & Steinthor & $50-59$ & Riding tours, horse rental \\
A-4 & female & Emma & $40-49$ & Riding tours, horse rental, horse breeding \\
A-5 & male & Jon & $50-59$ & Breeding, training, riding tours, horse shows \\
A-6 & female & Viktoria & $30-39$ & Breeding, training, competing, riding instruction \\
A-7 & female & Helga & $50-59$ & Breeding, training \\
A-8 & female & Eydis & $40-49$ & Breeding, riding tours, cultural tourism \\
A-9 & male & Arnar & $40-49$ & Breeding, training \\
A-10 & female & Indiana & $20-29$ & Riding tours \\
A-11 & male & Haraldur & $30-39$ & Breeding, training, horse tours, shoeing \\
A-12 & female & Eva & $40-49$ & Breeding, training, riding tours \\
A-13 & male & Svavar & $60-69$ & Riding tourist, breeding \\
A-14 & male & Kjartan & $40-49$ & Horse shows for tourists \\
A-15 & male & Holmar & $60-69$ & Breeding, training, riding instruction \\
A-16 & female & Hildur & $40-49$ & Breeding, riding instructions, farm tourism \\
A-17 & female & Sigrun & $50-59$ & Breeding, training \\
A-18 & male & Ottar & $40-49$ & Horse rental \\
A-19 & male & Hermann & $50-59$ & Breeding \\
A-20 & female & Katrin & $50-59$ & Breeding, training \\
A-21 & male & Valur & $60-61$ & Breeding \\
\hline
\end{tabular}

B. A convenience sample of 8 domestic horse tourists was approached in 2018, and asked to reflect on the topic in writing. Only two questions were posed; "Please describe your experience of riding trails and your preference for various types of trails". The respondents are anonymized by giving them a participant number (e.g., B-1). These accounts were gathered for this research on domestic equestrian tourists in Iceland and in preparation for a survey among domestic horse tourists in Iceland (Table 2).

Table 2. Demographics of responding domestic horse riders.

\begin{tabular}{ccc}
\hline No & Gender & Age \\
\hline B-1 & female & $50-59$ \\
B-2 & female & $60-69$ \\
B-3 & male & $40-49$ \\
B-4 & female & $30-39$ \\
B-5 & female & $50-59$ \\
B-6 & male & $50-59$ \\
B-7 & female & $60-69$ \\
B-8 & female & $50-59$ \\
\hline
\end{tabular}

C. The authors also reflected on their own experience by writing short autobiographical accounts of long distance riding, which are part of the results. These are anonymized C- 1 and C-2 and their demographics and background are shown in Table 3. 
Table 3. Demographics and equestrian experience of the authors.

\begin{tabular}{cccc}
\hline No & Gender & Age & Background \\
\hline C-1 & female & $50-59$ & Amateur rider and horse owner \\
C-2 & female & $40-49$ & Horse farmer, accredited trainer and hobby rider \\
\hline
\end{tabular}

\section{Results}

Based on the literature review and our autobiographical reflections we came up with the categories of trail attributes, trail experience and the economic trail. Analysis yielded the further categories of open spaces, experiencing landscapes, history and heritage. Further, the category of trail attributes was broken up into different attributes such as rough, natural, constructed. The category trail experience proved too restrictive as respondents speak of not only experiencing the trail, but also the experience emotions, the movement of the horse and the weather, to name a few topics discussed as experience. Hence, we speak of experiencing and subcategories of experience aspects (Figure 1).

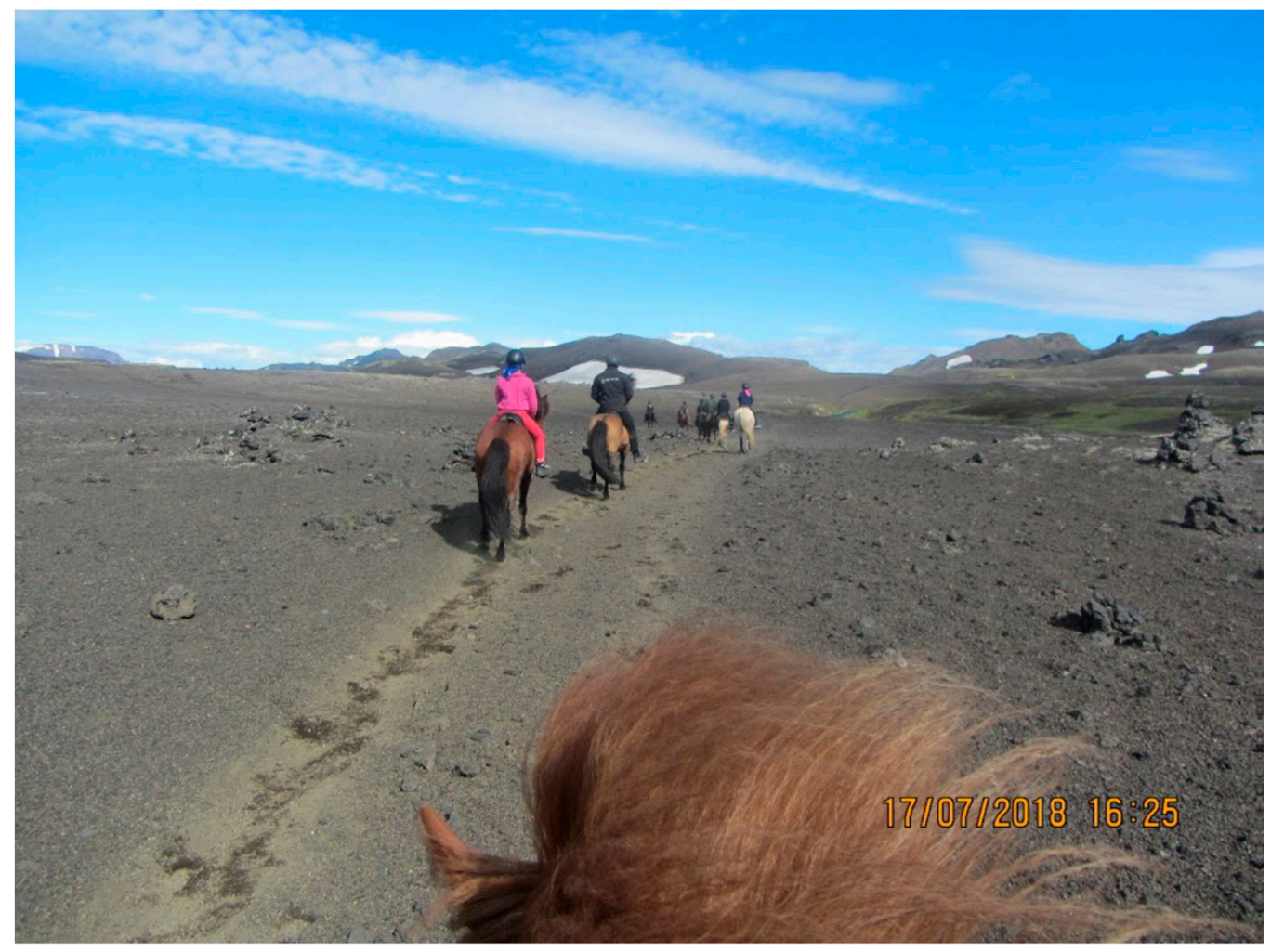

Figure 1. Riders in the highlands of Iceland. Photo: Ingibjörg Sigurðardóttir.

\subsection{Trail Attributes}

A recurring theme in the interviews is diversity, the respondents want trails that are not uniform but varied in terms of terrain, soil, gradient and the surrounding landscape. There is divergence in preference for highland and mountainous trails (B-2). C-1 admits "I guess I'm more of a flatland rider".

The trail that is easy on horses and riders, that is, soil that is firm yet yielding such as riverbanks, sands and mud trails are preferred by most. The natural trail, explained in more detail below is an ideal that many respondents refer to.

What all the respondents agree on is that trails for horses should be separate from vehicle traffic and preferably at a distance from roads and other traffic. 


\subsubsection{Trail Experience}

"I love it so much, it is such fun, everybody, everybody likes to take long rides and herd horses, it is just such fun and you experience the land totally differently and I just love it!" (A-7).

Riding is a multisensory experience and our respondents talk often about sight, sound and touch when describing how they experience trails. On horseback you sense "the scent of flora, of the soil and of the horse" making for a complex experience. Further being outside, exposed to the weather conditions, pleasantly as "the wind is tickling your cheek" (B-2) or as A-4, a horse tourism entrepreneur recalls a trip: "The weather was horrible, as horrible as can be in Iceland, but we just took shorter rides and proved to ourselves that everything is possible. Researcher: Is it part of the experience? It is part of the experience, we are not only selling horseback riding we are selling Icelandic nature and the horse in all its glory and a kind of moment that you can't plan. It just is, and we are catching it."

C-1 talks about the sounds of hoofs on the trail; beating like a drum on firm riverbanks, the crunch of the gravel on lava trails and the soft thuds on a dry mud trail in the tussocks.

Riding in nature also affords quiet, when you stop you only hear birds, breathing, wind and water, "except maybe for a jet in the high skies" says Valur A-21, horse farmer, who claims that this quiet connects him deeply to nature. Other respondents claim that the quiet in the mountain pastures is a unique experience (A-16; B-2).

An important part of the experience is how far you ride and how long you stay in the saddle. A-4 says that she has thought a lot about what is the perfect day trip or length of day in the saddle to keep the experience enjoyable and safe. Particularly as accidents tend to happen at the end of the day when horses and people are tired. She has as many horse tourism entrepreneurs, shortened the distances traveled and the number of hours in the saddle from what was usual for domestic riders experienced at long rides. C-1 likes her comfort and finds $3-5$ hours in the saddle and traveling about $30 \mathrm{~km}$ optimal.

\subsubsection{The Wide, Open Spaces}

One of our respondents explains that as a rider, you are elevated, which affords a better overview and brings into focus the landforms along the trail, whereas when hiking the flora is the immediate experience (B-1). The same respondent summarized the experience in Keywords: "View/Wide horizons—scent-speed/pace—movements/motion—trails/history—friend/connection".

"It is best to ride away from other traffic and enjoy the landscapes; a good tour takes you through different kinds of terrain over hill, over dale as it were" (C-1). C-2 agrees that riding along busy roads is not interesting, particularly not with a herd of free running horses.

When explaining the constraints he feels in his region one of the horse farmers said "we don't have the wide open spaces that you have in Húnavatnssýslur and Skagafjörður, where you can have herds of horses grazing" (A-3). A horse tourism entrepreneur considers himself fortunate in having enough land to be able to give experienced riders a bit of mountain experience, while the less experienced stay on the lowland trail (A-5).

The opportunity to range far and wide is seen as important for the horses, while it is also cherished by humans. The horse farmers we interviewed maintained that it is an important element in the training of horses in Iceland to let them stay in herds, that young animals learn from older animals how to be in the land and how to socialize. We need to emphasize that "the horse is a clever animal, as it can be when it is fostered in an environment where it must take care where and how to step and becomes strong from running in the mountains" (A-6). A-12 a horse entrepreneur agrees the terrain that makes the Icelandic horse so foot sure and reliable in different types of trails "it's no asphalt tracks here". A-16 talks about the different quality of life for an Icelandic horse in Iceland and other countries "To be a horse in this environment is like being born in Paradise and when you leave Paradise you become just another horse".

Her colleague A-7 agrees that the horse must have the freedom to run and roam "without the human always tagging along", that the horse must be allowed to be a horse, to be a herd animal 
and to be resilient and able to manage in nature without constant human interference. She feels sorry for the big horses in other countries who have lost this connection to other horses and nature "they are completely helpless, many of them and they can't even be together. They are kept in cages and cannot even meet other horses and such, I think it is terrible!" The owners need to be liberated as well, she mentions a group of women she met overseas and "they had just been plodding along in a riding hall in private lessons with an instructor-never went out to ride in the woods".

All the horse farmers also maintain that herding and traveling with horses is part of the training, claiming that it is not only important for the motor exercise but also in socializing the horse to run with a herd. However, those living in the peri-urban and urban areas feel more hemmed in and constrained, unable to give their horses the mountain experience that traditionally was so important. "You worry all the time if you have suddenly ridden into a garden or a golf course!" A-13 says.

\subsubsection{Experiencing Landforms with the Horse}

\section{The Rough Trail}

When riding the respondents feel and adapt to the trail with the horse; "you try to follow the motion of the horse, to merge with it-it's not so easy to merge with the motions of a Land Rover!" respondent B-1 says about riding rough trails. C-1 talks about working with the horse on the steep track, shifting the weight to ease the ascent and descent for both parties as a kind of bonding. This is however challenging and even unsafe for the inexperienced rider. One of the horse farmers we interviewed explains why bringing visitors to gather sheep and horses in his area is not a good idea:

The land is difficult, there are creeks and you cannot cross wherever ... and they often have trouble getting the horses across the brooks and creeks. The land is steep and difficult-we need land that is more flat for this! (A-3).

In one of our pilot interviews, an experienced rider shares the concern that tour groups cannot handle all types of terrain: "I love crossing rivers and lakes, but you cannot plan for swimming the horses when traveling in a group" (B-2). However, the rough terrain may entail different roles for the equine travel companion; that of a packhorse and to assist hikers for instance with crossing rivers and as a safety measure in case of exhaustion or injury. This is seen by some as an opportunity to develop hiking in mountainous and difficult areas (A-3).

An important part of riding is experiencing how the horse understands and responds to the land. C-2 points out that different kinds of surface and length of rides is chosen for different horses, depending on their age, training conditions and preferred gaits. Young and unexperienced horses are ridden for short distances and more experienced horses are used for longer and more challenging rides.

Many tales have been told of how horses have a keener sense of weather, better orientation and are more adept at choosing the path than humans. C-1 has personal experience of this, leading her unwilling horse into a bog that looked firm but the horse wanted to avoid. Needless to say, the horse was right.

\section{The Gentle Trail}

"Of course it is bliss to ride soft mud trails in between (although neither in drought or rain) and grassy riverbanks, not to mention the soft sands, but not only this type of land, it is absolutely essential that the soil is varied but not so stony that horses hurt themselves" (B-2).

"But the best is riding shallow water on tidal sands, when the water reaches just above the hoof and the sand is firm and the horses are frisky" (C-1).

\subsubsection{The Natural Trail—Trailing Naturally}

Many respondents mention freedom, not being constrained by a road, which is not always well adapted to the landscape, and preferring old and traditional trails that follow the landforms more naturally than new roads: "The old riding trails lie more naturally in the land, where it was most 
easily traveled. The trail gives you information that is not perhaps so obvious-the bog that it takes you around may seem harmless, but why then did the trail go around?" (B-1). C-1 talks also about this, "I like riding old trails made by hooves of horses and sheep on grasslands and moors. The riding trails made now are not terribly interesting, they are too often just by roads with vehicle traffic and the gravel and sand is sometimes really heavy and made for slow going. Sometimes good old mud trails have been damaged with gravel, which I do not like, and it rather invites other traffic, motorbikes and four-wheel drives. It is best to ride away from other traffic and enjoy the landscapes; a good tour takes you through different kinds of terrain over hill, over dale as it were" (C-1).

The importance of avoiding the driving traffic is clearly indicated. B-2 prefers riding in the highlands and mountainous areas: "It is best when the riding trail is mostly in uninhabited areas and at least far away from asphalt and vehicle traffic. And that it affords you the opportunity to explore-to learn about your land on the tour". "I'm not excited about riding or herding horses next to the highway" says A-20, horse farmer and trainer. C-2 also claims that riding on asphalt roads can be harmful for horses and even riders as the asphalt is slippery particularly when it is wet. It is also bad for the feet of the horses as it is a very hard substrate.

\subsubsection{Human and Animal Impact-History in the Trail}

"We would never have been able to settle this land if we hadn't had the horse with us" Kjartan A-14, horse tourism entrepreneur says about Icelanders. The connection with the land is not only about landforms but also history "When you ride them you also experience the history in the land, you understand better the connection between humans and nature and you understand nature better" (B-1). "Great fun to think through and try out traditional, ancient riding trails. History matters" (B-2).

A-6 is a horse farmer and for her riding through parishes where only the old roads and the ruins remain, is special and she believes very attractive for horse tourists as well. She uses gravel roads for training her horses as the terrain around her farm is wetland and does not have a lot of old trails that are still open but she thinks it would be interesting to reopen them.

C-1 is concerned when seeing new trails emerge in lava, destroying moss and prefers to hear the crunch of the gravel on existing trails in such landscapes. However, "multiple paths side by side in the tussocks don't bother me; they just suggest that this is an old trail used by animals and people for centuries even".

\subsection{The Economic Trail}

The touristic value of riding trails further indicates an economic value of those trails. As riding trails attract visitors, various services are being bought from locals in each region. Domestic riders travel with big flocks of horses, commonly 3 to 8 horses per person. All horses need a place to stay during the nights. In most cases, grass fields are being rented, but in the highland, hay has to be bought. The human travelers also need accommodation, meals and different kinds of services. Therefore, an attractive riding trail is likely to have economic effects on its community. Interviews with tour operators and other operators of horse based businesses indicated that riding trails are important infrastructure for their businesses and in fact a premise for their economic activities related to horses, as riding trails are needed to train horses so they can be sold, prepared for the use of locals and international visitors or shown as breeding horses. Those trails are also a premise for selling short and long riding tours.

\section{Discussion}

The study indicates that trails are of a considerable importance for the experience of domestic tourists traveling by horses in Iceland. The surface of the trails and its geographical surroundings are commonly seen as vital affecting factors regarding the total experience of the riders. Companionship with the horses and the human traveling companions were among affecting factors. The riding trail and its surroundings was particularly emphasized as important for the total experience of the riders. 
The riders' descriptions are romantic and winged. Even very "down-to-earth" people have a twinkle in their eyes, a smile on their face and become romantic when describing the memory of riding a "good" riding trail in a long riding tour.

The findings of the study support our definition of horse riders as casual geotourists and important stakeholders in the conservation and use of geosites, such as riding trails and their surroundings. Geosites have different kinds of values to different stakeholders. Scientific, educational, touristic, cultural, heritage and scenic values have been described in recent studies $[16,17,20]$. The respondents of this study clearly indicate that many of those values exists regarding riding trails.

B-1 and C-1 described a mixture of educational and cultural/heritage values of riding old riding trails and how the horse-human relation is strengthened through the shared experience of negotiating the terrain. In that way, the geosites or the riding trails along with the horses have an educational role to the riders during the travel, and at the same time, traveling the ancient trails traveled for centuries has cultural/heritage value.

Touristic value of both ancient trails and new trails is considerable, as those trails are being used in touristic purposes both by domestic riders traveling on own horses and by foreign visitors traveling with horse tourism businesses. The ancient trails are more preferred as they are commonly situated away from motorized traffic. The touristic value of the trails is also mentioned by $\mathrm{C}-1$ as she describes how decisions about where to ride and what areas to visit are based on the quality of the riding trails and how attractive they are to the riders. This is in line the findings of Blackwell et al. [36] where improvement of trails and facilities showed to be likely to increase the number of revisits and length of stay. Interestingly, despite the fact that riders prefer "improvements" of trails domestic and international riders in Iceland do not highly emphasize the safety of riding trails. Riding interesting, varied and suitable long riding trails seems to be of more importance to those riders [3], which might be an indicator of the adventurous nature of the riding tours. For the international riders the geological aspect of the trails may be exotic, and feel challenging for their skills as riders and may raise concerns for the welfare of horses on these rough trails.

An increasing number of people have limited access to nature in their everyday life. Ólafsdóttir [59] discusses the importance of 'getting back to nature' to deal with the strain and stress of everyday life. The opportunity of using leisure riding in the same purpose is mentioned by Cochrane and Dashper [37] where they describe leisure riding in open countryside as a way "to remove themselves physically and emotionally from the stresses of everyday life". The strongest theme, regarding the value of enjoying a ride on a preferred riding trail can be defined as an emotional value. Related to the emotional value, a romantic value can be defined. Most of the respondents of this research become emotional/romantic when they describe their experience of riding a 'good' riding trail. They describe the experience as magnificent, celestial and invigorate. They also talk about experiencing a whole new world, becoming part of the nature and the universe and getting into seventh heaven. For those people the trail and its surroundings have an emotional value, which seems to be of great importance for their total experience of the riding tour.

The importance of landscape for future development of equestrian tourism is apparent in the findings of this study. Specific landforms are more preferred depending on the purpose of the riding tour and the group of travelers. It can be argued that specific landforms or surface of trails can be dangerous for unexperienced riders, but preferred by some of the more experienced riders, who are out for more challenging conditions. This study reveals an undiscussed but important link between landscape and future development possibilities of equestrian tourism where different landforms play a significant role in product development in equestrian tourism and highly affect personal experience of the riders.

As this is an initial attempt to link equestrian tourism and geotourism, the study has limitations that call for further research. A stronger transdisciplinary focus is needed where geology and tourism studies knowledge and method would be more equally applied, whereas this paper relies more on tourism studies. It is our hope that this contribution will engender interest among geotourism and 
geoheritage researchers in equestrianism as an issue for further study. Furthermore, data collection was limited to Iceland, which limits the generalizability of findings. An interesting avenue of research would be a comparative study of different horse cultures and landscapes globally.

\section{Conclusions}

The delimitation of this study was domestic equestrian tourist experience on long rides in Iceland. Previous research on international equestrian tourists on the same trails suggests a difference in experience. For many of the international tourists the terrain, type of trail and the culture of horsemanship in Iceland is exotic and may feel challenging both for riders and horses, although the latter are native to the land. For both groups the sensory experience of the trail and of riding is powerful and results in a high emotional value of traveling with horses on natural trails.

Furthermore, our research indicates that both domestic and international visitors spend considerable amounts of money on their trips for accommodation, food and drink for people and horses. These hotspots of economic activity on the riding trails, leave money trails of great and potentially even greater importance to the rural areas and rural tourism in Iceland.

This study adds a new angle to the discussion on geosites by arguing that riding trails and its surroundings can be defined as geosites. Further, this study suggests that trails do have different kinds of values as other geosites. Recent studies suggest that geosites can have values such as touristic, cultural, heritage, scientific and educational values. Additionally this study suggests that riding trails can have both economic values and emotional value for its stakeholders.

The preference that the domestic riders have for natural trails, that is, trails made by animals, traditional trails and trails away from other traffic, particularly motorized, has implications for geosite management. As these domestic riders are also locals in the various areas and sites with designated geoheritage, they represent one of the interests of the local communities that is access and freedom of travel. Given the pressure on Icelandic geosites from increasing international tourism, it is likely that conservation involves further restrictions on access. In the planning and preservation, the interests of non-motorized domestic travelers such as horse riders are an important stakeholder and community engagement issue.

Author Contributions: Conceptualization, G.H. and I.S.; Methodology, G.H. and I.S.; Validation, G.H. and I.S.; Formal Analysis, G.H. and I.S.; Investigation, G.H. and I.S.; Resources, Hólar University College and University of South-Eastern Norway; Data Curation, G.H. and I.S.; Writing-Original Draft Preparation, G.H. and I.S.; Writing-Review \& Editing, G.H. and I.S.; Visualization, I.S.; Supervision, G.H.

Funding: This research received no external funding.

Conflicts of Interest: The authors declare no conflict of interest.

\section{References}

1. Kozak, M.W. Making trails: Horses and equestrian tourism in Poland. In Equestrian Cultures in Global and Local Contexts; Adelman, M., Thompson, K., Eds.; Springer, Cham: Basel, Switzerland, 2017; pp. 131-152.

2. Sigurðardóttir, I.; Helgadóttir, G. Upplifun og pjónusta. Íslenskir gestir í hestaleigum. Landabréfið 2006, 22, 37-47. (In Icelandic)

3. Sigurðardóttir, I.; Helgadóttir, G. Riding high: Quality and customer satisfaction in equestrian tourism in Iceland. Scand. J. Hosp. Tour. 2015, 15, 105-121. [CrossRef]

4. Bischoff, A. Mellom Meg og det Andre er der Stier ... En Avhandling om Stier, Mennesker og Naturopplevelse. Ph.D. Thesis, Norwegian University of Life Sciences, Ås, Norway, 2012.

5. Ólafsdóttir, R.; Dowling, R. Geotourism and geoparks-A tool for Geoconservation and Rural Development in Vulnerable Environments: A case study from Iceland. Geoheritage 2014, 6, 71-87. [CrossRef]

6. Newsome, D.; Moore, S.A.; Dowling, R.K. Natural Area Tourism: Ecology, Impacts and Management, 2nd ed.; Channel View Publications: Bristol, UK, 2012; Volume 58.

7. Hose, T.A. Selling the Story of Britain's Stone. Environ. Interpret. 1995, 10, 16-17. 
8. Newsome, D.; Dowling, R. The scope and nature of geotourism. In Geotourism; Elsevier: Oxford, UK, 2006; pp. 3-25.

9. Ólafsdóttir, R.; Tverijonaite, E. Geotourism: A Systematic Literature Review. Geosciences 2018, 8, 234. [CrossRef]

10. Erfurt-Cooper, P. Introduction to volcano and geothermal tourism. The context of volcano and geothermal tourism. In Volcano \& Geothermal Tourism, Sustainable Geo-Resources for Leisure and Recreation; Erfurt-Cooper, P., Malcolm, C., Eds.; Earthscan: London, UK, 2010; pp. 3-31.

11. Sturød, A.G.; Helgadóttir, G.; Nordbø, I. Unpublished Work.

12. Helgadottir, G. Horse round-ups: Harvest festival and/or tourism magnet. In Cheval, Tourisme $\mathcal{E}$ Sociétés/Horse, Tourism E Societies; Pickel-Chevalier, S., Evans, R., Eds.; Parution: Paris, France, 2015; pp. 216-223.

13. Sigurðardóttir, I. Wellness and equestrian tourism-New kind of an adventure? Scand. J. Hosp. Tour. 2018, 18, 377-392. [CrossRef]

14. Helgadóttir, G.; Sigurðardóttir, I. Horse-based Tourism: Community, Quality and Disinterest in Economic Value. Scand. J. Hosp. Tour. 2008, 8, 105-121. [CrossRef]

15. Helgadottir, G. The culture of horsemanship and horse based tourism in Iceland. Curr. Issues Tour. 2006, 9, 535-548. [CrossRef]

16. Mígorí, P.; Pijet-Míogrí, E. Viewpoint geosites-Values, conservation and management issues. Proc. Goel. Assoc. 2017, 128, 511-522. [CrossRef]

17. Brilha, J. Inventory and qualitative assessment of geosites and geodiversity sites: A review. Geoheritage 2016, 8, 119-134. [CrossRef]

18. Necheş, I.-M. Geodiversity beyond material evidence: A geosite type based interpretation of geological heritage. Proc. Geol. Assoc. 2016, 127, 78-89. [CrossRef]

19. Panizza, M. Geomorphosites: Concepts, methods and example of geomorphological survey. Chin. Sci. Bull. 2001, 46, 4-5. [CrossRef]

20. Erikstad, L.; Nakrem, H.A.; Markussen, J.A. Protected geosites in an urban area of Norway, inventories, values, and management. Geoheritage 2018, 10, 219-229. [CrossRef]

21. Timothy, D.J.; Boyd, S.W. Heritage tourism in the 21st century: Valued traditions and new perspectives. J. Herit. Tour. 2006, 1, 1-16. [CrossRef]

22. Dabezies, J.M. Heritagization of nature and its influence on local ecological knowledge in Uruguay. Int. J. Herit. Stud. 2018, 24, 1-15. [CrossRef]

23. Adams, W.M.; Hutton, J. People, parks and poverty. Political Ecology and Biodiversity Conservation. Conserv. Soc. 2007, 5, 147-183.

24. Bradbury, J. A keyed classification of natural geodiversity for land management and nature conservation purposes. Proc. Geol. Assoc. 2014, 125, 329-349. [CrossRef]

25. National Geographic Society. Geotourism Principles. Available online: https://www.nationalgeographic. $\mathrm{com} / \mathrm{maps}$ /geotourism/geotourism-principles/ (accessed on 12 September 2018).

26. Gordon, J.E. Geoheritage, Geotourism and the Cultural Landscape: Enhancing the Visitor Experience and Promoting Geoconservation. Geosciences 2018, 8, 136. [CrossRef]

27. Reynard, E.; Brilha, J. Geoheritage: Assessment, Protection and Management; Elsevier: Amsterdam, The Netherlands, 2017; p. 482.

28. Council of Europe. European Landscape Convention. European Treaty Series No. 176. 2000. Available online: https:/ /rm.coe.int/1680080621 (accessed on 15 May 2018).

29. Food and Agriculture Organization of United Nations. Horses in Iceland. Available online: http:/ / www.fao. org/faostat/en/\#compare (accessed on 26 May 2018).

30. Sigurðardóttir, I.; Helgadóttir, G. The new equine economy of Iceland. In The New Equine Economy in the 21st Century; EAAP Scientific Publications 136; Evans, R., Vial, C., Eds.; Wageningen Academic Publishers: Gelderland, The Netherlands, 2015; pp. 225-236. [CrossRef]

31. Ferðamálastofa. Ferðapjónusta á Íslandi í Tölum. 2018. Available online: https:/ /www.ferdamalastofa.is / is/tolur-og-utgafur / ferdtjonusta-i-tolum (accessed on 10 October 2018). (In Icelandic)

32. Pickering, C.M.; Hill, W.; Newsome, D.; Leung, Y.-F. Comparing hiking, mountain biking and horse riding impacts on vegetation and soils in Australia and the United States of America. J. Environ. Manag. 2010, 91, 551-562. [CrossRef] [PubMed] 
33. Beeton, S. The cost of complacency: Horseback tourism and crisis management revisited. Curr. Issues Tour. 2002, 5, 467-470. [CrossRef]

34. Newsome, D.; Cole, D.N.; Marion, J.L. Environmental impacts associated with recreational horse-riding. In Environmental Impacts of Ecotourism; Buckley, R., Ed.; CABI Publishing: Wallingford, Cambridge, UK, 2004; pp. 61-82.

35. Newsome, D.; Smith, A.; Moore, S.A. Horse riding in protected areas: A critical review and implications for research and management. Curr. Issues Tour. 2008, 11, 144-166. [CrossRef]

36. Blackwell, M.; Pagoulatos, A.; Hu, W.; Auchter, K. Recreational demand for equestrian trail-riding. Agric. Res. Econom. Rev. 2009, 38, 229-239. [CrossRef]

37. Cochrane, J.; Dashper, K. Characteristics and needs of the leisure riding market in the United Kingdom. In Cheval, Tourisme E Sociétés/Horse, Tourism \& Societies; Pickel-Chevalier, S., Evans, R., Eds.; Parution: Paris, France, 2015; pp. 82-91.

38. Pórðarson, H.; Sigurðardóttir, I. Reiðleiðir á vestanverðum Tröllaskaga. In Fræðaping landbúnaðarins; Jónsdóttir, R.S., Ed.; Bændasamtök Íslands, Landbúnaðarháskóli Íslands, Landgræðsla ríkisins \& Skógrækt ríkisins: Reykjavík, Iceland, 2015; pp. 384-386. (In Icelandic)

39. Schmudde, R. Equestrian tourism in national parks and protected areas in Iceland-An analysis of the environmental and social impacts. Scand. J. Hosp. Tour. 2015, 15, 91-104. [CrossRef]

40. Ólafsdóttir, R.; Runnström, M.C. Assessing hiking trails condition in two popular tourist destinations in the Icelandic highlands. J. Outdoor Recreat. Tour. 2013, 3, 57-67. [CrossRef]

41. Samgönguráðuneytið. Stefnumótun í Ferðapjónustu; Hagvangur hf: Reykjavík, Iceland, 1996. (In Icelandic)

42. Gunnarsdóttir, G.P.; Helgadóttir, G.; Sigurðardóttir, I.; Bollason, K.; Haraldsdóttir, L.; Broddason, P.; Árnason, P. Ferðapjónusta í Skagafirði, Stefnumótun 2006-2010. Gæði og gleði; Gunnarsdóttir, G.P., Árnason, P., Eds.; Sveitarfélagið Skagafjörður: Sauðárkrókur, Iceland, 2006. (In Icelandic)

43. Sigurðardóttir, I.; Steinthorsson, R.S. Establishment and downfall of a horse based cluster initiative in Northwest Iceland. Contemp. Issues Law 2017, 14, 217-230.

44. Sigurðardóttir, I.; Steinthorsson, R.S. Equestrian tourism in Northwest Iceland: An emerging micro-cluster of horse related activities. Scand. J. Hosp. Tour. 2018, 18, 261-277. [CrossRef]

45. Nordbø, I.; Prebensen, N.K. Hiking as mental and physical experience. In Advances in Hospitality and Leisure; Chen, J.S., Ed.; Emerald Group Publishing Limited: Bingley, UK, 2015; Volume 11, pp. 169-186.

46. Dowling, R. Emerging volcano and geothermal related tourism in Iceland. In Volcano E Geothermal Tourism, Sustainable Geo-Resources for Leisure and Recreation; Erfurt-Cooper, P., Malcolm, C., Eds.; Earthscan: London, UK, 2010; pp. 209-220.

47. Evans, R.; Sigurðardóttir, I.; Helgadóttir, G. A good practice guide to equine tourism. Developing native breed equine tourism in the North Atlantic region. Available online: http:/ /hlb.no/wp-content/uploads / 2017/04/HLB_rapport_2_2015_final.pdf (accessed on 10 October 2018).

48. Evans, R. Riding native Nordic breeds: Native breeds as cultural heritage development in Nordic countries (Norway, Iceland, Scotland and the Faroe Islands). In Cheval, Tourisme E Sociétés/Horse, Tourism E Societies; Pickel-Chevalier, S., Evans, R., Eds.; Parution: Paris, France, 2015; pp. 188-204.

49. Wilson, R.T. Animal genetic resources and domestic animal diversity in Nepal. Biodivers. Conserv. 1997, 6, 233-251. [CrossRef]

50. Buckley, R.; Ollenburg, C.; Zhong, L. Cultural landscape in Mongolian tourism. Ann. Tour. Res. 2008, 35, 47-61. [CrossRef]

51. Cassidy, R. The horse, the Kyrgyz horse and the 'Kyrgyz horse'. Anthropol. Today 2009, 25, 12-15. [CrossRef]

52. Nordbø, I.; Sagyntay Kyzy, E. Health tourism and horse milk therapy in Kyrgyzstan. In Health, Tourism and Hospitality. Spas, Wellness and Medical Travel; Smith, M., Puczkó, L., Eds.; Routledge: London, UK, 2014; pp. 341-344.

53. Stefánsdóttir, G.J.; Ragnarsson, S.; Gunnarsson, V.; Janson, A. Physiological response to a breed evaluation field test in Icelandic horses. Animal 2014, 8, 431-439. [CrossRef] [PubMed]

54. Hafstein, H. Ljóðmæli; Bókaútgáfa Menningarsjóðs: Reykjavík, Iceland, 1944. (In Icelandic)

55. Ólafsson, P. Ljóđmæli; II bindi. Aldar Prentsmiðja: Reykjavík, Iceland, 1900. (In Icelandic)

56. Thomsen, G. Skúlaskeið. Available online: http://wayback.vefsafn.is/wayback/20041122111457/www. sogusetur.is/Syningar/skald18.htm (accessed on 20 June 2018). (In Icelandic) 
57. Pickel-Chevalier, S.; Grefe, G. Représentation et symbolisme du cheval: La révolution contemporaine, interprétée à travers les arts cinématographiques et littéraires populaires. In De l'imaginaire Universel du Cheval aux Enjeux Prospectifs des Chevaux dans les Territoires; Presses Universitaires de Caen: Caen, France, 2017; pp. 109-128.

58. Schutt, R.K. Investigating the Social World: The Process and Practice of Research; Pine Forge Press: Newbury Park, CA, USA, 2011.

59. Ólafsdóttir, G. ' ... sometimes you've just got to get away': On trekking holidays and their therapeutic effect. Tour Stud. 2013, 13, 209-231. [CrossRef]

(C) 2018 by the authors. Licensee MDPI, Basel, Switzerland. This article is an open access article distributed under the terms and conditions of the Creative Commons Attribution (CC BY) license (http:// creativecommons.org/licenses/by/4.0/). 